\title{
TWO PIECES OF UNCOLLECTED WHITMAN JOURNALISM: "WASHINGTON AS A CENTRAL WINTER RESIDENCE" AND "THE AUTHORS OF WASHINGTON"
}

\author{
Martin G. MurRay
}

WALT WHITMAN's Washington period (1863-1873) was remarkably prolific. ${ }^{1} \mathrm{He}$ wrote nearly one hundred new poems, including the DrumTaps series, the Lincoln elegies, and Passage to India (both the poem and the book by that name). Two new American editions of Leaves of Grass were published, as well as an authorized British selection of his poems. Whitman's prose ranged from his poignant correspondence on the Civil War wounded for the New York press, to a series of political and literary essays that became Democratic Vistas. The poet's personal life also was enriched with a large circle of friends. In any given week, Whitman might be found attending the music halls with Peter Doyle, bird-watching with John Burroughs, arguing politics with Ellen and William O'Connor, and discussing the law with Charlie Eldridge. Now we can add to this productive period two pieces of uncollected journalism written for the Washington Evening Star in 1872. These articles attest to Whitman's affection for his adopted home and to his immersion in the life of the city. The Evening Star, edited by Crosby Stuart Noyes, was the city's leading daily and published several other articles by Whitman during his Washington residency. ${ }^{2}$

The first of the two uncollected articles, entitled "Washington as a Central Winter Residence," appeared in the January 6, 1872, Evening Star, on page 4 immediately following the editor's mast, and lauds the artistic and scientific milieu of the capital city in the post-Civil War period. It highlights institutions that were the city's important incubators for arts, literature and science, such as the Corcoran Art Gallery, the Library of Congress, and the Smithsonian Institution. This article ends by referring the reader to a second piece, on the front page of the January 6, 1872, edition of the Star, also very likely written by Whitman. Succinctly titled "The Authors of Washington," the two-part article (it continued on the front page of the January 9, 1872, edition) enumerates some seventy published writers, and represents possibly the most extensive assembled reading list for the poet at a given point in time. Characteristically broad, the list encompasses popular fiction writer 
Emma (E.D.E.N.) Southworth, journalist George Alfred Townsend, poet Sarah Bryan Piatt, naturalist John Burroughs, jurist Charles Nott, physician John Billings, astronomer Simon Newcomb, and librarian A. R. Spofford.

Although neither article is signed, Whitman's authorship is strongly suggested by extant Whitman manuscripts that appear to have served as draft portions of the published articles. In addition, the articles are redolent thematically and stylistically of Whitman's work, as we will see.

\section{Washington as a Central Winter Residence.}

${ }^{1}$ The growing tendency seems more and more pointing to the gradual establishment of superior and permanent advantages in this city for a general first class winter residence. ${ }^{2}$ The Americans are migratory and like change of scene. ${ }^{3}$ To those who can afford it - wherever they go in summer, flitting abroad, or to the uttermost parts of the land-it is getting to be generally agreed they cannot do better than rendezvous here for the winter. ${ }^{4}$ Thus Washington is gradually, and we think, surely forming a distinctive metropolitan American character. ${ }^{5}$ Perceptible centers of Literature, Science, Art, and Society are already here and are rapidly crystalizing. ${ }^{6} \mathrm{With}$ the growing advantages here these circles once formed will rapidly expand. ${ }^{7}$ The great Corcoran Art Gallery will form an art nucleus for the country. ${ }^{8}$ The Congressional Library, already one of the first-class libraries of the world will, so soon as the intelligent views of Mr. Spofford are carried out, be the most beneficent and useful. ${ }^{9}$ The Smithsonian Institution, the Naval Observatory, Coast Survey, Hydrographic and Signal offices, with other public departments, gather here a body of scientific men of the highest attainments, such as are found collected nowhere else in the country. ${ }^{10}$ Students are coming here from all parts of the country to the three colleges of the District, because of the special advantages over educational institutions elsewhere afforded here in the libraries, the scientific collections, the Botanic Gardens and conservatories, the Government Anatomical Museum, the pleadings in the Supreme Court, and the debates in Congress.

${ }^{11} \mathrm{O}$ the attractions of Washington socially nothing need be said, as so much has already been written on this point. ${ }^{12}$ These attractions must, however, be greatly increased as the city is adorned, improved, and made equal in comfort and elegance to its natural advantages of position and climate. ${ }^{13}$ For the first time in the history of Washington the city has streets sufficiently well paved to allow of pleasure-driving every day through the winter, and the brilliant spectacle on Pennsylvania avenue of an afternoon is a foretaste of what the future will show when the wealth of the country shall congregate here, as it is beginning to do, for its winter Newport or Saratoga. ${ }^{14}$ From the enumeration given in another column of the number of writers who now make their homes here, it will be seen that Washington is growing to be a literary center also. ${ }^{15}$ The number will doubtless increase year by year. 


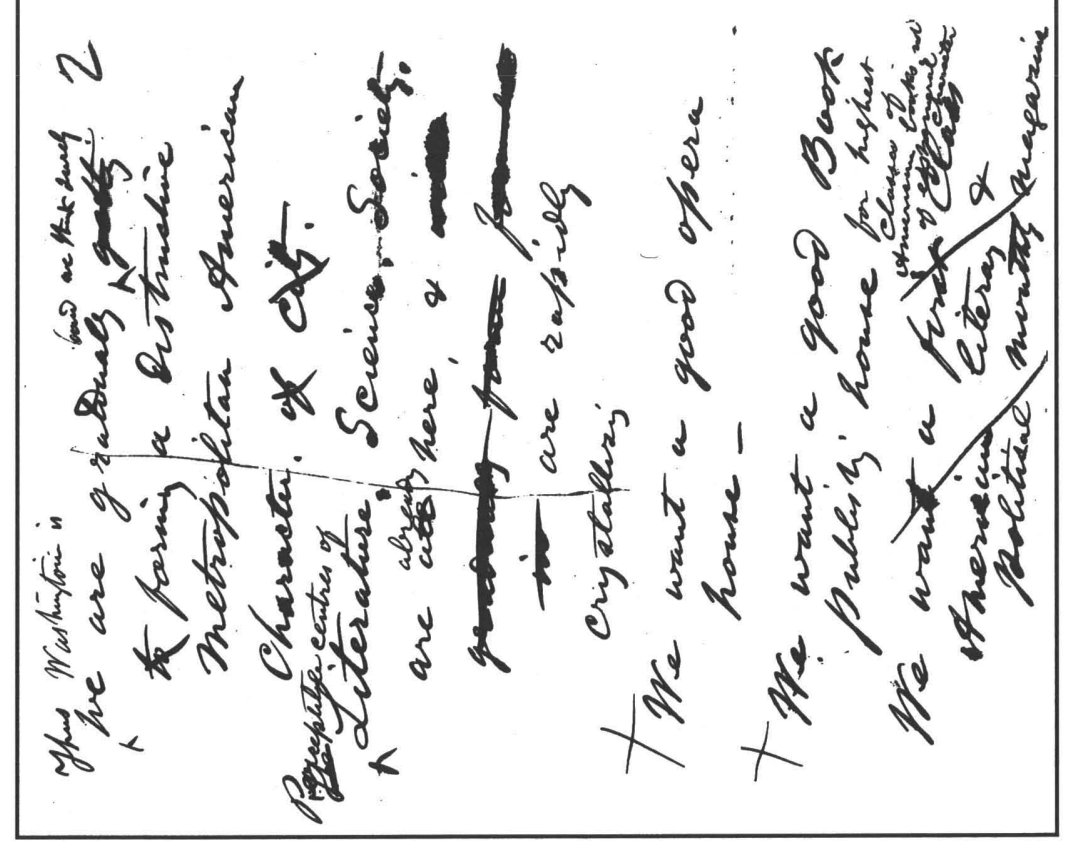

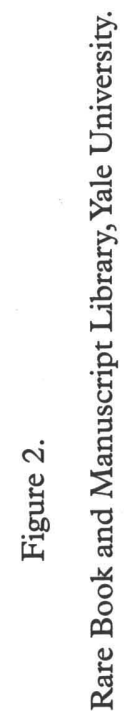

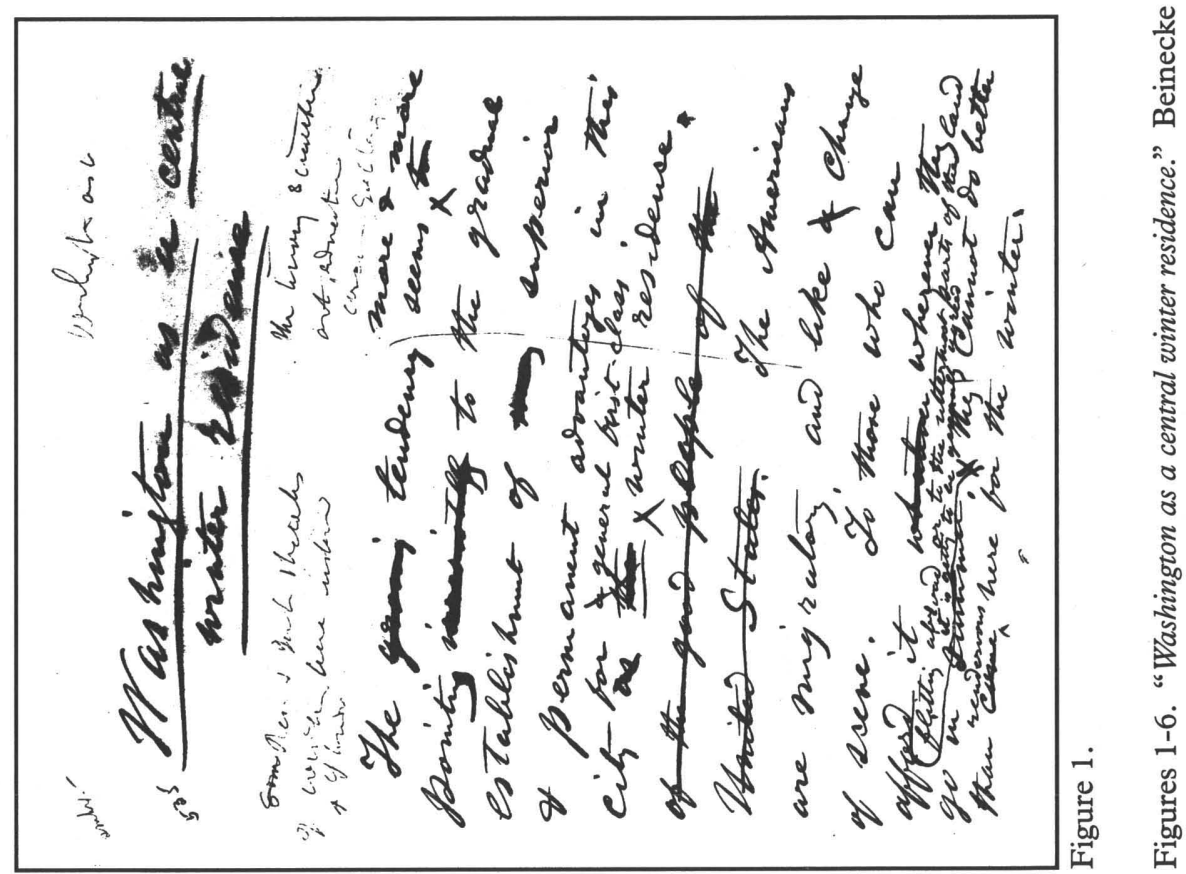




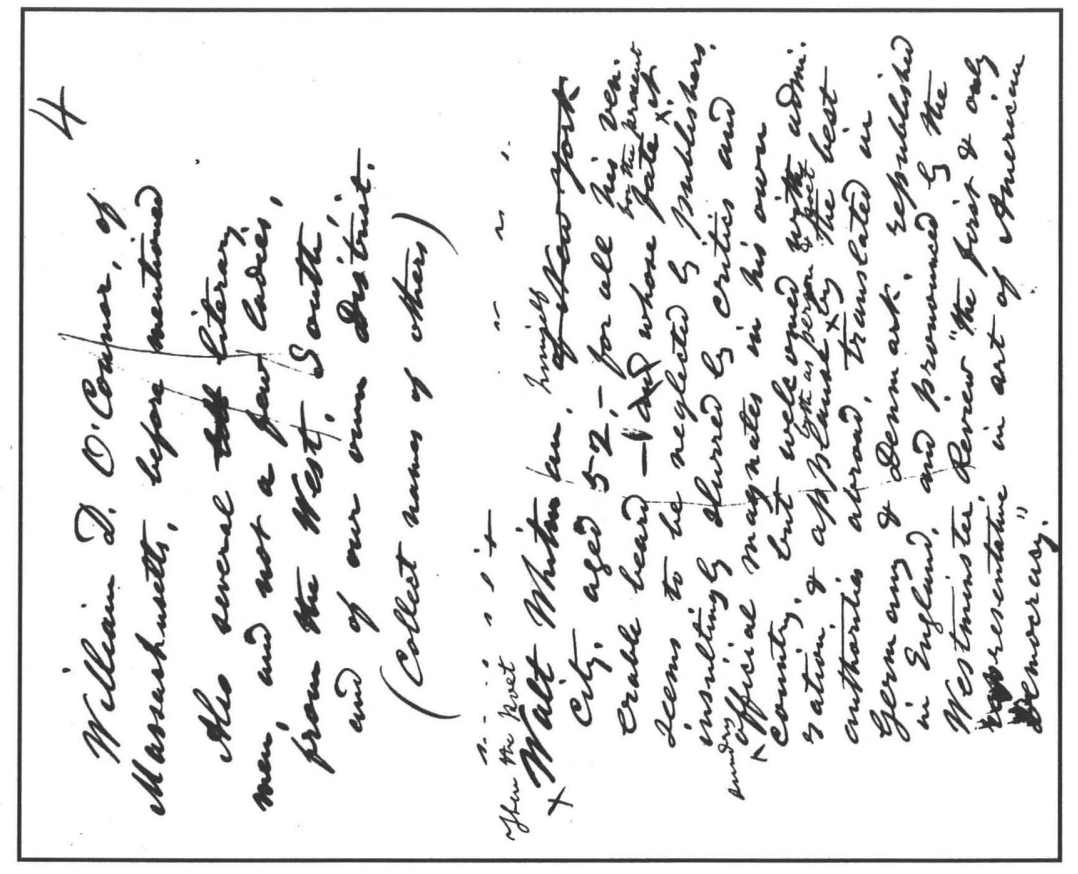

نं

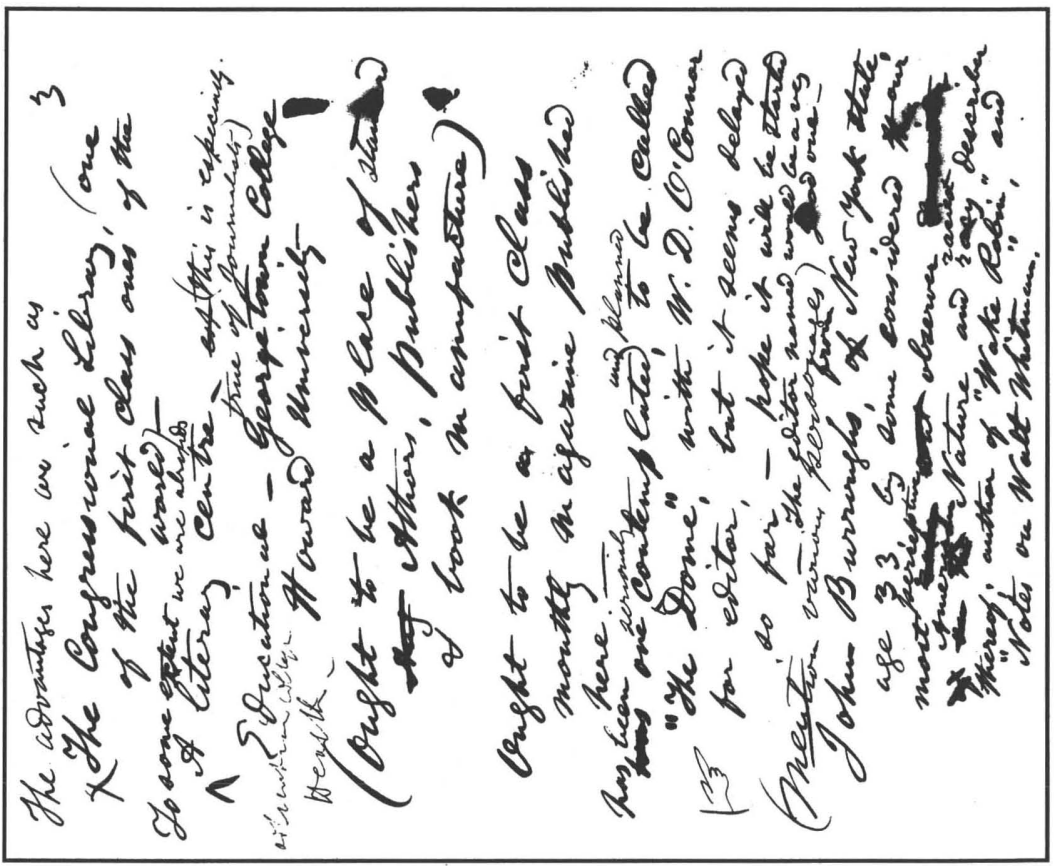

๗. 


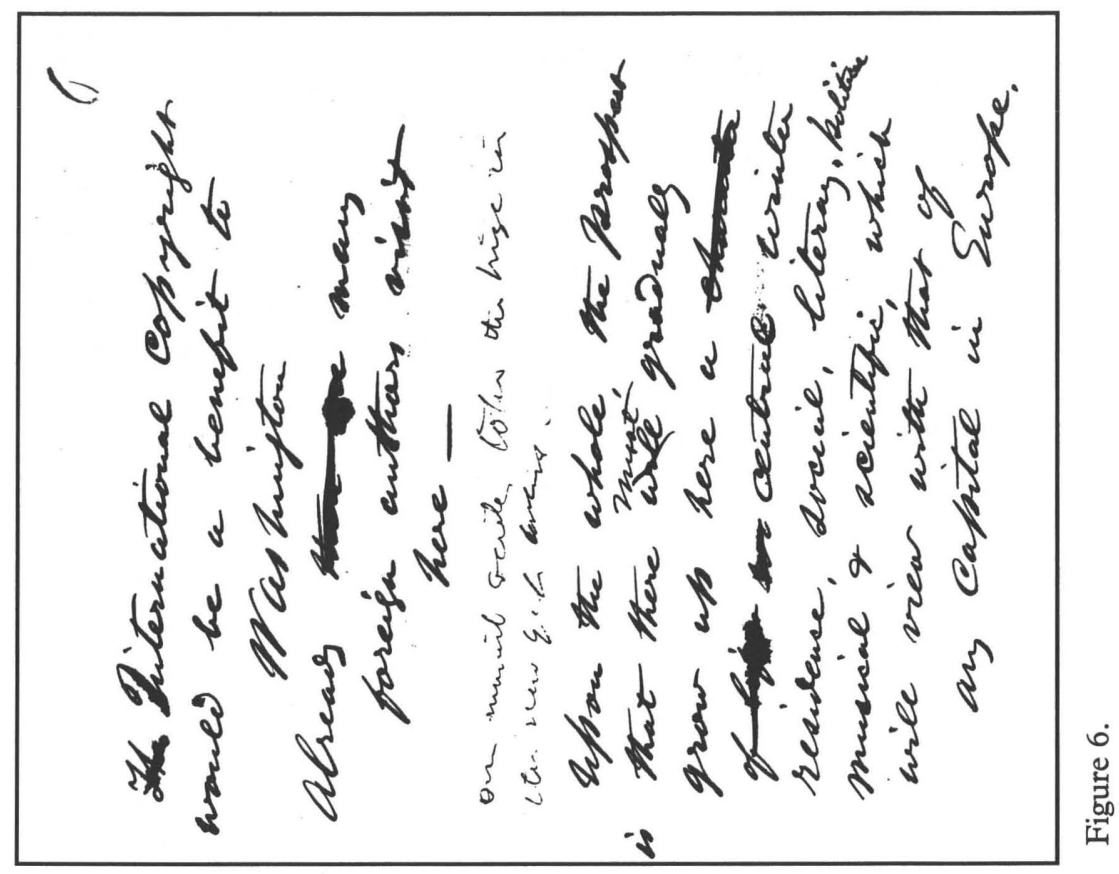

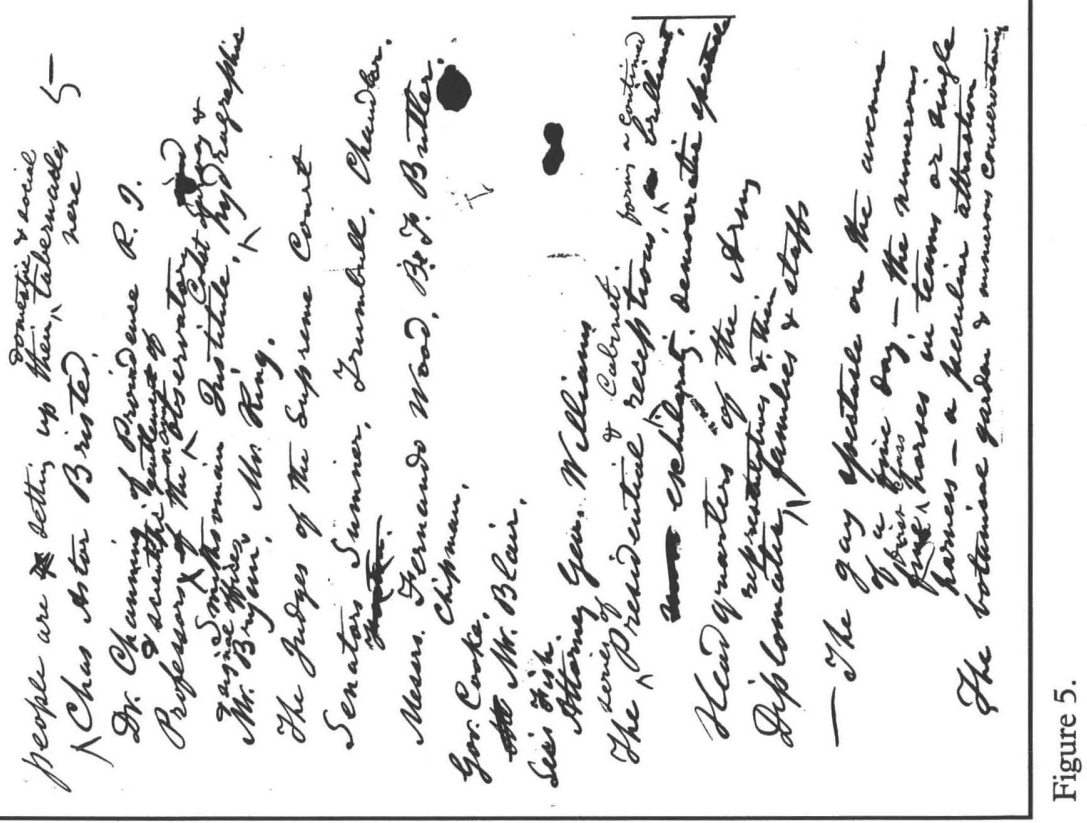


${ }^{16}$ Upon the whole, the prospect is that there must gradually grow up here a central winter residence, social, literary, political, musical, and scientific, which will vie with that of any capital in Europe.

Support for Whitman's authorship of "Washington as a Central Winter Residence" is found in an undated Whitman manuscript that is part of the Walt Whitman collection in the Beinecke Rare Book and Manuscript Library at Yale University. The manuscript consists of six numbered sheets of paper (see figures 1 through 6 ). The title and first three sentences of the Evening Star article are virtually verbatim as the lines from the first manuscript sheet: ${ }^{3}$

\section{Washington as a central}

winter residence

[illeg] [illeg] ${ }^{4}$

The growing tendency seems more \& more to

pointing irresistibly to the gradual

establishment of many superior

\& permanent advantages in this

city as the for a general first-class winter residence.

of the good people of the

United States. The Americans

are migratory, and like a change

of scene. To those who can

afford it whatever wherever they

go in summer, flitting abroad or to the uttermost parts of the land it is getting to be generally

agreed they cannot do better

than eome rendezvous here for the winter.

Similarly, the fourth and fifth sentences of the newspaper article are nearly identical to the first two sentences of the second manuscript sheet:

Thus Washington is We are gradually and we think surely getting

to forming a distinctive

Metropolitan American

Character. of eity.

The Perceptible centres of Literature, Science, Society,

are alt ${ }^{\text {already }}$ here, \& will 
gradually form formulate

in are rapidly

crystallizing

The eighth, tenth, and fourteenth sentences of the newspaper article correspond to the top portion of the third manuscript sheet:

The advantages here are such as The Congressional Library, (one

of the first class ones of the

$$
\text { world)- }
$$

To some extent we are already A literary centre-esp (this is especially

true of Journalists)

Educational-Georgetown College

Columbian College Howard University

Health

The remaining sections of the third manuscript sheet and all of the fourth manuscript sheet were incorporated in the "Authors of Washington" article, discussed below.

Portions of the fifth manuscript sheet correspond to sentences 9, 10,11 , and 13 of the newspaper article:

people are ge setting up their domestic \& social tabernacles here

Professors \& scientific gentlemen of of the naval observatory

Smithsonian Institute, Coast Survey $\&$ hydrographic

\& signal offices,

The Judges of the Supreme Court

- The gay spectacle on the avenue

of a fine day - the numerous

fine first class horses in teams or single

harness-a peculiar attraction

The botanical garden \& numerous conservatories 
The final sentence of the newspaper article is nearly identical to the final sentence on the sixth manuscript sheet:

\author{
Upon the whole, the prospect \\ is that there ${ }^{\text {must }}$ gradually \\ grow up here a eharaeter \\ of life we central winter \\ residence, social, literary, political \\ musical \& scientific, which \\ will view with that of \\ any capital in Europe.
}

The published article, then, corresponds to the extant Whitman manuscript in twelve of its sixteen sentences, as well as its title, and thus can safely be attributed to Whitman.

The second article, "The Authors of Washington," was published in two installments in the Washington Evening Star. The first installment appeared on Saturday, January 6, 1872, in the same edition as "Washington as a Central Winter Residence."

\title{
THE AUTHORS OF WASHINGTON.
}

\section{WHO THEY ARE, AND SOMETHING ABOUT THEM.}

From various causes, among others the mildness of the climate, the libraries and scientific collections for reference, the opportunity for government employment or newspaper letter-writing not incongenial with literary pursuits, Washington is growing to be a literary center. The list of writers who are authors - have written books - is a pretty long one, and if to these were added the magazinists and letter-writers who have written much and well, but have not yet figured in binding, the roll would stretch out almost indefinitely.

We have here, and making their homes here, Walt Whitman, Albert Pike; Mrs. Lippincott, ("Grace Greenwood,") Mrs. Southworth, George Alfred Townsend, ("Gath,") Professor Joseph Henry, Ben Perley Poore, ("Perley,") A.R. Spofford, Charles Astor Bristed, ("Carl Benson,") Charles Lanman, Harriet Prescott Spofford, Helen C. Weeks, Dr. J. M. Toner, the three Piatts-Donn Piatt, John James Piatt and his wife, Mrs. S. B. Piatt, (formerly Sarah M. Bryan of the Prentice-Louisville fournal, galaxy of poets)-William D. O'Connor, Mrs. Baden, Dr. T. S. Verdi, John Burroughs, L.A. Gobright, Mrs. Eastman, R. J. Hinton, Mrs. Bouligny, De B. R. Keim, Dr. Howard, F. C. Adams, Miss Esmeralda Boyle, and others whose names do not for the moment occur to us. 
As above indicated, a number of the writers here are Department clerks, or the wives of clerks. The great body of the clerks here in government employ are men of culture and intelligence, and they form an element of our population not to be overlooked in estimating the position which Washington is destined to take in literature and science. It would seem, with such a large writing element in our midst, that a first-class monthly magazine ought to succeed here; and, in fact, one has been seriously contemplated and planned, to be called "The Dome," with

\section{W. D. O'CONNOR}

for editor. Mr. O'Connor, who is a clerk in the Treasury Department, has displayed fine capacity as a magazine writer, and very likely would do well as an editor, though the ability to write does not always indicate the ability to edit. $\mathrm{He}$ is a native of Massachusetts.

\section{JOHN BURROUGHS,}

who has been mentioned as a probable contributor to the new magazine, is also a Department clerk, and is getting famous through his admirable articles on natural history in the Atlantic Monthly. He already takes rank as our most perceptive observer of American Nature, and raciest describer thereof. Mr. Burroughs is the author of "Wake Robin;" and "Notes on Walt Whitman," being an enthusiastic admirer of "the good gray poet." Mr. Burroughs, aged 33, is a native of New York.

Then the poet

\section{WALT WHITMAN}

is a clerk in the Attorney General's office. His age is but 52, despite his venerable beard. For the present it seems to be his fate to be neglected by publishers, insultingly slurred by critics and sundry official magnates in his own country, but welcomed with admiration and applause both as person and poet by the best authorities abroad, translated in Germany and Denmark, republished in England, and pronounced by the Westminster Review "the first and only representative in art of American Democracy."

\section{HELEN C. WEEKS,}

who is probably the most popular writer of stories for children next to Miss Alcott, is the wife of a department clerk, Dr. Weeks, the individual who brought down upon himself such a storm of popular objurgation for his plain speaking at the Social Evil Meeting at Lincoln Hall. Mrs. Weeks is the author of "Grandpa's House," "The Ainslie Stories," "White and Red; a Narrative of Life among the Northwest Indians," and is a prominent contributor to "Our Young Folks" and "The Riverside Magazine."

Quite certainly the name of no writer turns up oftener than that of George Alfred Townsend, whether as author, magazinist, or letter-writer. It is next to impossible to take up a newspaper without coming upon some extract credited to "G.A.T." or to "Gath," his Chicago Tribune nomme de plume:

\section{GEO. ALFRED TOWNSEND}

is of Eastern Shore, Maryland, extraction, and was born at Georgetown, in Delaware, 1841. He was educated at Washington and Delaware Colleges, on "the Peninsula," and at the Philadelphia High School. He began to 
publish tales and verses in 1856, and in 1859, the day after graduating, went on the daily press, and was managing editor of the Philadelphia Inquirer, and afterward city and dramatic editor of the Press. In 1862 he was correspondent of the New York Herald with the army in McClellan's and Pope's campaigns. After this he went to Europe, and was a contributor to the Cornhill Magazine, Chambers' fournal, the St. Fames, and the Social Science Review. After nearly two years' absence he returned to New York and became the descriptive writer on the World, giving that paper the chief eclat of the kind it has ever had in letters on the close of the rebellion. Simultaneously he edited the New York Citizen, and made the paper "wicked" on Tammany Hall, where General Halpine had made it merely lively. About the same time he published "The Crime of J. Wilkes Booth" and "The Real Life of Lincoln," pamphlets, and "The Campaigns of a NonCombatant!" In this and the two succeeding winters, he lectured above 200 nights in every part of the country, on such topics as: "Europe Armed," "The Lands to the North of Us," "The Pennsylvania Dutch," "What Governs Us," etc. In 1866 he went to see the war between Prussia, Austria and Italy, and in 1867 attended the Paris exhibition, doing his best work for the New York Tribune. In the spring of 1868 he moved to Washington. He is naturally an independent political writer, and his presence here was instantly acknowledged. He signalized his advent by making a rupture between the President-apparent, Mr. Wade, and the Western republican journals, which lightened the fall of what were called the recalcitrant republican Senators. Vigor, diligence, versatile reading, a fecund fancy and a sweeping diction, occasionally let down to humor, made the new writer's audacity formidable in political writing. Since 1868 he has published two bulky volumes: "The New World Compared with the Old" and "Lost Abroad, a romaunt," and a book of poems, and written for the general newspaper press, leading the list with the Chicago Tribune, which has paid him $\$ 20,000$ for 1,000 columns preferred matter, furnished at the rate of 300 columns per annum. Although producing so much matter of nearly equal merit, Mr. Townsend never appears to have anything on his mind, and he is the youngest looking correspondent here. Although aggressive, he has never written anything calling for an explanation or denial in Congress. He has declined to take editorial charge of leading Journals in New York and the west, and entertains the hope that he may leave journalism altogether at some early day and follow pursuits more purely literary. $\mathrm{He}$ is married and has two children; his only brother is a skillful surgeon in Philadelphia, the protege of Doctor Gross and other eminent professors. His father is also a physician and has been a member of the Philadelphia M. E. conference for nearly forty years.

Another name familiar in print as "household words" is that of BEN PERLEY POORE.

Major Poore was educated for the bar, but has always preferred the exciting and unrestrained life of a Bohemian. When a lad, he escaped from the luxuries and comforts of home, to work as an unknown apprentice in a 
printing office for two years, where he acquired the art and mystery of typography. Arriving at years of discretion, and having travelled all over this country, he passed five years abroad, frequenting courts and revelling with students, but all the while becoming more averse to his profession, and the more pleased with a connection which he formed with the Boston Atlas, as its European correspondent. Returning to this country in 1847, he married in Georgetown, which was the birthplace of his mother, and where he had first began to visit in 1828, when John Quincy Adams was President. He wrote his first letters for publication from Washington in 1838, '39, and '40; but did not become a regular Washington correspondent until his return from France in 1847, since when he has contributed a vast amount of metropolitan news, by mail and by telegraph. After the dissolution of the Boston Atlas he became the regular correspondent of the Boston fournal, and his communications over the signature of "Perley" during the past nearly twenty years have added much to the deserved popularity of that paper. $\mathrm{He}$ also, before losing the sight of an eye a few years since, used to correspond with the New York Commercial Advertiser and the New Orleans Times, while his contributions have long appeared in Harper's Weekly. Major Poore has also written several books, among them "The Rise and Fall of Louis Philippe," "The First Campaigns of Napoleon I.," and a score or more of novelettes, which originally appeared in Gleason's Pictorial, and were afterwards published in a more permanent form. As clerk of the printing records of the Senate, he edits the "Congressional Directory," the annual "Abridgement of Executive Documents" and the "Law of the United States" in a very acceptable manner. It is no secret, however, that his great work is to be his own "Personal Reminiscences," which are based on his private journals and his printed correspondence, and which will give some curious accounts of what he must have seen and heard here, behind the curtain of the congressional stage.

\section{MRS. SOUTHWORTH.}

The career of Mrs. Southworth, the novelist, has been a remarkable one, made up of bitter trials, hardships and triumphs. She was born in this city, December 26 th, 1819 , is consequently 52 years old, and though cheerful and courageous says she would not be a day younger if she could. Her father was Charles Lecompte Nevitt, at one time a flour merchant in Alexandria, and her mother was a native of St. Mary's county, Maryland. Of her unhappy marriage, and her subsequent career as a "Deserted Wife," it is unnecessary here to speak further than to say that the history is every way creditable to her. It was at this time, when she was struggling to support herself and two little children on the pittance of $\$ 20$ per month as schoolteacher, and by sewing nights, that she made her first venture for publication, a little story called "The Irish Emigrant," which she sent to the Saturday Visitor, a weekly paper then published in Baltimore. It was published, with a request for "more," and thus encouraged, she wrote for the Visitor "The Wife's Victory," in April, 1846. A few weeks after, the paper stopped, and 
the subscription list was bought by Dr. Gamaliel Bailey, who had started the National Era in Washington, an anti-slavery paper, and in which Mrs. Stowe's "Uncle Tom's Cabin" first appeared. Mrs. Southworth's story was transferred to the Era, with the subscription list of the Visitor, and on her visiting the Era office to get a copy, she made the acquaintance of Dr. Bailey. He was very kind, and warmly encouraged her to continue her literary work. She wrote several stories for the Era in the summer of 1846, and then finding other duties pressing and pen-work not remunerative, she wrote no more until near Christmas. Although her stories were copied into many papers, showing their popularity, yet she could not afford to write for glory alone, and she stopped, disheartened. The Era was not well established, and Dr. Bailey, though a liberal-hearted man, was not able to pay her for her work; the school fund, on which her miserable salary of $\$ 20$ per month depended, gave out at this time, and she was reduced to great stress for the necessaries of life for herself and little ones. One dreary day in December, 1846, while she was writing, after school-hours, in the cold shool-room, waiting for the girl to bring her over-shoes and umbrella, a carriage drove up to the door, Dr. Bailey entered in haste and asked her to write a Christmas story for the Era, at the same time putting a sum of money into her hands-a very large sum to her in those gloomy days. When he went away she felt that her fortune was made. Her anti-slavery doctrines-though born a slaveholder - had made her unpopular with the patrons of the school, and somewhat so with the Board of Trustees. The situation, wearing and unremunerative at best, was also precarious in its tenure, and the visit of Dr. Bailey promised both freedom and congenial occupation. She wrote at this time a story for the Era called "Temptation," which ran through several numbers. After this her abolition principles got her into hot-water again; she felt it her duty to free a negro in dispute, and this involved her in some difficulties so that she was hindered from writing for some months. In the meantime, John G. Whittier, the Quaker poet, wrote to Dr. Bailey inquiring why Mrs. Southworth did not write for the Era. Dr. B. communicated this fact to Mrs. Southworth, and she was again raised from the depression caused by her difficulties and discouragements, by the praise of an author of the standing of Whittier. She felt like going on again, and then commenced the novel "Retribution," which made her known to the world. She began, intending to complete it in two or three numbers, but it expanded under her hands and grew in popularity as it progressed. Several of the literary people of the north wrote to Dr. Bailey, and called his attention to its great merits. At that time serial novels were not republished in book form; but, encouraged by the good opinion of competent critics, Mrs. Southworth sent "Retribution" to the Harper's, after it had appeared in weekly chapters in the Era, though with no great hope of success, as they had never before published a novel under these circumstances. The Harper's gave it to their reader, Henry J. Raymond, (afterward the founder of the New York Times,) who pronounced a favorable opinion upon it, but advised an alteration in one 
of the chapters, which Mrs. Southworth could not, at the time, understand. It was in the scene where Juliet escapes from a too ardent lover by setting her teeth into his hand. Raymond advised that it might be modified or left out; but Mrs. Southworth, strong in her convictions of what was effective in the story, declined to change the passage. After Mr. Raymond's death, it was stated of him that he never was in a passion in his life, and this fact afforded a clue to Mrs. Southworth why he failed to comprehend how a beautiful and fascinating woman could be moved to bite-even in self-defence. "Retribution" was published by the Harper's in August, 1847, and at once took a strong hold upon popular favor; and that hold the author retains undiminished after writing continuously for more than a quarter of a century. Following upon the publication of "Retribution," Mrs. Southworth was invited to write for the Philadelphia Saturday Evening Post, a literary paper of wide circulation at that time, and she contributed serials to that paper until 1856. She had just concluded a long novel for the Post, and had been resting for some weeks at her cozy "Prospect Cottage," on Georgetown Heights, (the comfortable home that now replaced the dingy tenement she had occupied on south 13th street, when struggling to support her family on $\$ 20$ a month,) when she was visited by Robert Bonner of the New York Ledger. His keen eye detected her rising popularity, and he was determined to secure her for the Ledger. He told her, in his direct off-hand way, that he did not know what she was receiving for her pen-work, but whatever it was he would double it. She named the pay she was receiving, and he not only doubled the sum, but added a handsome bonus and made it a fixed salary on a contract to write five years exclusively for his paper. As the Ledger grew in circulation, $\mathrm{Mr}$. Bonner liberally increased her salary before the termination of this first contract. At this time her stories were all copied in England, and translated and copied in German and French papers. In 1856 an agent of the London fournal came over to get the manuscript, and if not, advance sheets of her stories. By the liberal consent of Mr. Bonner she was able to make an advantageous arrangement with the fournal. In 1859 she was invited to go to England to try to get authorship copyright there by residence, as her stories were steadily pirated by European publishers. She went over with her family for this purpose, and served an injunction on a guilty publisher, but got a chancery suit instead of a copyright. She spent three years in England, writing during her stay for the London fournal, but primarily for the Ledger. She took out letters of introduction from Mrs. Stowe to the Duchess of Sutherland, who received her very affectionately at Stafford House; and to Lady Noel Byron, who became one of her warmest friends. She also had letters to the Kingsley brothers, Charles and Henry, the Martineaus, and others of literary note, so that she had the opportunity of spending as much time in distinguished literary and social circles as she could spare from her busy pen. The chancery suit was finished in December, 1861, adversely to her, and she was heartily glad to have done with the delays of English laws 
and to get home. On reaching home in 1862, she found new work before her in the needs of the sick and wounded soldiers in our hospitals, and she entered upon it with all the earnestness of her nature. It was in this work that she contracted the fever (varioloid) that so seriously threatened her life.

Mrs. Southworth has by her hard and unremitting work with the pen reached comfortable circumstances. She continues the leading contributor to the Ledger, and Bonner the most liberal of employers. Since she has been on the Ledger, Charles Dickens, Alfred Tennyson, Edward Everett, George D. Prentice, Henry Ward Beecher, Fanny Fern, James Parton and many others known to fame have "written for it," but no one of them, nor all together, could ever send the circulation of that paper up at a bound as does the announcement of "a new story by Mrs. Southworth." It is common to account for her success by calling her stories sensational, but if anybody thinks it an easy matter to write successful sensation stories, or any other kind, for twenty-six years continuously, let them try it - or let them try one, even! But let any one review the Southworth novels and he will be surprised by the small amount of sensation matter in them. No current writer in fact deals so little with murder and bigamy, the standard material for modern sensation fiction, as does Mrs. Southworth.

Since Mrs. Southworth commenced writing in 1846 she has produced no less than thirty-two novels. Of these "The Hidden Hand," published in 1859, is the most popular. It has been dramatized in England and America, and still holds the stage. Capitola hats, Capitola fast horses, and Capitola schooners have been named for its heroine; and various points about the Island of Mount Desert, down towards sunrise, have received their appellations from the same source. Mrs. Southworth's favorite, however, is her story of "Self-Made," founded on the life of William Wirt, and which embraces many interesting particulars of his career known to her ancestors.

It will be remembered that Charles Reade was accused of plagiarism in his "Terrible Temptation" by appropriating his mad-house description verbatim from a book called "illustration of Madness," published in 1810. A similar charge is suggested by Mrs. Southworth in her preface to "Fair Play, or the Test of the Lone Isle," on its appearance in book form. Her story, which bears so much resemblance to Reade's "Foul Play," as might lead any reader of both novels to suspect a plagiarism on the one side or the other, was first published in the New York Ledger, and copied in the London fournal in 1865 and 1866. "Foul Play" was published in 1868.

Mrs. Southworth in person is quite unlike the ideal of a "sensation writer." Tallish in figure with full forehead, well-balanced head, thoughtful gray eyes and a face denoting intellect of the deliberate reasoning kind, she seems likelier to be a writer of the Martineau order than of the imaginative style. She has two children, Dr. Richard J. Southworth, a much esteemed physician of Georgetown, and Charlotte Emma Lawrence, the wife of Dr. James V. Lawrence, an officer in the United States army. 
- But we are at the end of our space, and our sketch matter of the authors of Washington must "be continued."

The second installment of "Authors of Washington" was published in the Washington Evening Star on Tuesday, January 9, 1872.

\section{The Authors of Washington.}

The article on this subject in The Evening Star of Saturday last, embraced sketches of a very few only of the writers of books who reside at the national capital. Deferring for the present our sketches of the history and characteristics of others of our citizens who have been active contributors to the press, we give below a running list of some writers, not named in the former article, with a brief mention of the works by which they are best known.

Prof. Spencer F. Baird, author of many monographs on natural history, and of "The Birds of North America;" Dr. Albert G. Mackay, whose numerous standard works on Freemasonry are everywhere known; George W. Paschal, author of an elaborate work of annotations on the constitution of the United States, and of several volumes of law reports; Judge Charles C. Nott, author of "Sketches of the War," "The Seven Great Mediaeval Hymns," and, in connection with Judge Huntington, of the Reports of the Court of Claims; W. R. Hooper and N. S. Dodge, copious contributors to the magazines and newspapers; Theodore Gill, whose specialty is ichthyology, writer of numerous papers in scientific journals; Rowland Cox, compiler of an extensive work on the law of trade marks, and other legal works; Gen. A. A. Humphreys, author of "The Physics and Hydraulics of the Mississippi River;" P. Phillips, author of "The Statutory Jurisdiction and Practice of the Supreme Court of the United States;" Miss Martha Thomas, whose novel, "Life's Lesson," was published by the Harper's many years years ago; Darius Lyman, jr., whilom an Oxford (Ohio) Professor, now of the Treasury Department, and author of "Leaven for Doughfaces," "The Proverbs of Publius Syrus Translated," and many critical papers on the gospels; Prof. Benjamin Peirce, whose many works on physics and mathematics have given him a world-wide reputation; Prof. Simon Newcomb, author of "Our Financial Policy During the Southern Rebellion," and many papers on astronomical science; James C. Welling, President of Columbian College, a writer of scholarly papers in many periodicals; Edward McPherson, compiler of the very useful "Political History of the United States During the Rebellion," and of the "Political Manual" for every year since; S. J. W. Tabor, for many years an active contributor of critical and political articles to the press; Prof. J. E. Hilgard, one of the most genial scholars and fertile writers in the ranks of our scientific men; Nathan Sargent, the "Oliver Oldschool," of the New York press, who divides with Mr. E. Kingman the honor of being the Nestor among living Washington journalists, and who is about to publish his political recollections of nearly half a century; Mr. Kingman himself, the "Ion" of the Baltimore Sun, whose terse and masterly political correspondence once made him a power in the land; J. R. Dodge, 
author of "The Red Men of the Ohio Valley," a book on "West Virginia," and the industrious statistician of the Agricultural Department; J. B. Russell, librarian of the same department, for forty years editor, publisher and printer, whose hand still wields the pen in occasional historical articles for the press; Dr. N. C. Towle, whose "History and Analysis of the Constitution" has passed through several editions; Joseph J. Woodward, M.D., author of a volume of poems, and of numerous valuable contributions to microscopic science; Rev. Charles B. Boynton, author of "The Four Great Powers," "A Journey Through Kansas," a work on Russia, and the History of the Navy of the United States during the Rebellion; Samuel Tyler, whose "Burns as a Poet and a Man," "The Baconian Philosophy," "Progress of Philosophy," and "Life of Chief Justice Taney," with several works in jurisprudence, mark the literary student as well as the learned law professor; Charles D. Drake, Chief Justice of the Court of Claims, author of a learned Treatise on the Law of Suits by Attachment, and of many speeches and letters on Politics, gathered into book form; Mrs. Mary Clemmer Ames, author of "Eirene, or a Woman's Right," and of letters innumerable in the Independent; D. W. Bartlett, author of "Modern Agitators and Reformers," and Lives of Presidents Pierce and Lincoln, Joan of Arc and Lady Jane Grey, compiler of two volumes of "Contested Election Cases," and a busy correspondent for the daily and weekly press; W. L. Shoemaker, writer of many poems for popular magazines; Rev. J. P. Newman, author of "From Dan to Beersheba," etc.; Prof. S. M. Shute, whose "Manual of Anglo-Saxon" was recently published; James Schouler, author of an elaborate treatise on "The Law of Domestic Relations," and editor of "The United States Jurist," published here by Morrisons; Emily H. Reed, writer of a "Life of A. P. Dostie, and the Conflict at N. Orleans;" Mrs. A. H. Ruter Dufour, author of many poems in the newspapers, etc.; George Taylor, author of "Indications of the Creation; or, the natural evidences of a final cause," a scientific work several times printed; John S. Billings, whose exhaustive work on Barracks and Hospitals was published last year by the Surgeon General's Bureau; Th. Poesche, author of "The New Rome," and of papers on ethnology, etc.; Dr. C. C. Cox, long an editor and writer for medical and other journals on literary and scientific topics; George A. Otis, a writer of reports and books on surgical subjects; and the list of names and writings might doubtless be considerably extended.

The case for Whitman's authorship of the "Authors of Washington" is less obvious than for "Washington as a Central Winter Residence." Only a relatively small portion of "Authors" directly corresponds to the extant Yale manuscript, but the article's themes and writing style are certainly indicative of Whitman. The opening sentence of "Authors" is essentially a synopsis of "Winter Residence," with an amplification of one of its premises, namely that "Washington is growing to be a literary center." In fact, this latter clause repeats verbatim a portion of the fourteenth sentence in "Winter Residence," which specifically refers the reader to the "Authors" article ("From the enumeration given in another column of the number of writers who now make their homes here, 
it will be seen that Washington is growing to be a literary center also"). In addition, the opening sentence repeats key words of the first article (including "libraries," "scientific collections," "literary center," and the principal verb, "grow"), which, as previously noted, have counterparts in the Yale manuscript. ${ }^{5}$ This explicit connection between the two articles strongly suggests a common author.

Whitman clearly contributed the profiles of O'Connor, Burroughs, and of Whitman himself found in the third, fourth, and fifth paragraphs of "Authors," since these closely correspond to the author profiles in the Yale manuscript (bottom halves of page 3 and page 4):

Ought to be a first class

monthly magazine published

here.-

was has been one seriously contemplated, and planned to be called

“The Dome," with W. D. O'Connor

for editor, but it seems delayed

so far-hope it will be started

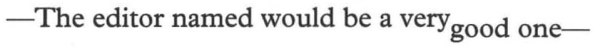

(Mention various personages)

John Burroughs, of from New York state,

age 33 , by some considered the our

most raey perceptive writ observer \& writer

of our the American Nature, and raey raciest describer

thereof; author of "Wake Robin," and

"Notes on Walt Whitman."

...

Then the poet Walt Whitman, himself of New York

City, aged 52,-for all his ven-

erable beard-and-whose fate for the present ${ }_{\text {it }}$

seems to be neglected by publishers,

insultingly slurred by critics and

sundry official magnates in his own

country, but welcomed with admi-

ration, \& applause both as person \& poet by the best

authorities abroad, translated in

Germany \& Denmark, republished 
in England, and pronounced by the

Westminster Review "the first \& only

representative in art of American

Democracy."

Significantly, both the manuscript and the published article slightly misquote the Edward Dowden essay from the Westminster Review. Dowden noted that Whitman was regarded "in a general way" as "the representative in art of American democracy." Dowden offered his own nuance on this, describing Whitman as "the first representative democrat in art of the American Continent," but he did not describe Whitman as "the first \& only representative in art of American Democracy."

The one sour note in the entire article, perhaps not surprisingly, is found in the description of Whitman. A strong sense of neglect by his own countrymen was weighing down Whitman's spirit, as indicated in the manuscript as well as in a letter he drafted to Dowden a week or so following the article's publication. In the letter, Whitman grouses:

There is one point touched by you in the Westminster criticism that if occasion again arises, might be dwelt on more fully - that is the attitude of sneering denial which magazines, editors, publishers, "critics" \&c. in the U. S. hold toward "Leaves of Grass." As to "Democratic Vistas" it remains entirely unread, uncalled for here in America. If you write again for publication about my books, or have opportunity to influence any forthcoming article on them, I think it would be a proper \& even essential part of such article to include the fact that the books are hardly recognized at all by the orthodox literary $\&$ conventi[on] al authorities of the U. S. - that the opposition is bitter, \& in a large majority, \& that the author was actually turned out of a small government employment $\&$ deprived of his means of support by a Head of Department at Washington solely on account of having written his poems. (Corr. 2:154-155)

The succeeding profiles of Helen Campbell Weeks, Benjamin "Perley" Poore, George Alfred Townsend, and Emma Southworth, have a more incidental relationship to the Yale manuscript. However, as previously noted, the manuscript does emphasize the role of journalists in the literary society of Washington, and Poore and Townsend were two of Washington's most prominent newspapermen. Although Southworth and Campbell were not journalists per se, their fictions were featured in popular magazines. The profiles of Campbell, Poore, Townsend and Southworth are noticeable for their attention to the authors' personalities and careers, rather than literary analysis or criticism. Ezra Greenspan has identified this non-analytic approach to fellow authors as characteristic of Whitman, evident for example in Whitman's reaction to Wordsworth: 
To read Whitman on Wordsworth with the expectation of being lifted to a higher plane of insight is to be disappointed. . . In clipping out the opening and closing pages of a review of the Prelude from the 1851 American Whig Review, Whitman, as he often did, paid less attention to what was said of the poetry than to the reviewer's brief summary of the poet's life and character-that was his primary text. His lone comment was elicited by the reviewer's allusion to Wordsworth's various appointments and legacies: "So it seems Wordsworth made 'a good thing,' from the start, out of his poetry. legacies! a fat office! pensions from the crown!" Similarly, in several other articles about Wordsworth he took the trouble to clip and save, Whitman exhibited a primary (and occasionally rather gossipy) interest in the poet as man-his appearance, manner, and bearing. ${ }^{7}$

Certain subjects touched upon in the four author profiles suggest a mix of Whitman's concerns and interests. "Voices of prostitutes" are curiously raised in the profile of the popular author of juvenilia, Helen Campbell Weeks. The Townsend sketch alights on the Civil War, Lincoln's life and assassination, battles with Tammany Hall, and opposition to Senator Benjamin Wade and the Radical Republicans over the Johnson impeachment. Poore shares Whitman's training as a printer's apprentice and a youthful bohemianism, followed by a journalistic and government career livened by broad literary interests and accomplishments.

The Southworth profile features her defiance of gender and marital stereotypes in her own life and those of her fictional heroines. It notes her association with the anti-slavery movement, early critical affirmation by a literary Brahmin, her ministrations on behalf of wounded Civil War soldiers, and a principled refusal to alter her work to satisfy an editor's demand. Southworth's battle against plagiarism and her personal fight to establish copyright protection in England is highlighted. Whitman had the copyright issue in mind at that moment, as indicated in the Yale manuscript notation that "International copyright would be a benefit to Washington." ${ }^{8} \mathrm{He}$ also complained in a letter written at this same time to Rudolf Schmidt, that, "while I, the author, am without any recompense at all in America, the English pirate-publisher, Hotten, derives a handsome annual income from a bad \& defective London reprint of my Poems" (Corr. 2:152). Whitman owned a copy of Reade's Foul Play, the book that the article accuses Reade of plagiarizing from Southworth (Corr. 2:124).

The Southworth sketch touches upon appellations, one of Whitman's particular fascinations; ${ }^{9}$ the author expresses great delight in the ubiquity of racehorses, schooners, and locales named after Capitola, the spunky heroine of Southworth's The Hidden Hand. Finally, the sketch takes pains to dispel the notion that Southworth is a "sensational story" writer as was popularly claimed, arguing instead that "no current writer in fact deals so little with murder and bigamy, the standard material for modern sensation fiction, as does Mrs. Southworth." In Democratic Vistas (1871), Whitman expressed disgust 
with the modern novelist who succeeds by "strik[ing] the mean flat average, the sensational appetite for stimulus, incident, persiflage, \&c., and depicts, to the common calibre, sensual, exterior life" (PW 2:407).

Whitman, of course, was an early admirer of Southworth's fiction. In "Letters from a Travelling Bachelor" (1849-185), he heralded the novelist's arrival:

NEW AMERICAN AUTHORESS.-Mrs. Emma D. M. Southworth, (whose novel of "Retribution" was published a few months ago by the Harpers,) is a new American authoress, of unusual native grace and vigor. With a very little more practice, and the exercise of - what is perhaps hard to a female writer-condensation, she will take rank among the best literary women of the land. ${ }^{10}$

The two extensive enumerations, one in each installment of the "Authors," also are good indicators of Whitman's authorship; he was a compulsive enumerator, and the catalogue is a characteristic feature of his poetry. The enumeration in the second installment is presented as a parataxis of syntactic parallelisms (author, subject, title), which James Perrin Warren has identified as a distinguishing feature of Whitman's poetic catalogues. ${ }^{11}$ In fact, in the very Westminster Review article cited by Whitman above, Edward Dowden provides a description of a Whitman catalogue that effectively describes the enumerations in " $\mathrm{Au}$ thors":

No single person is the subject of Whitman's song, or can be; the individual suggests a group, and the group a multitude, each unit of which is as interesting as every other unit, and possesses equal claims to recognition. Hence the recurring tendency of his poems to become catalogues of persons and things. Selection seems forbidden to him; if he names one race of mankind the names of all other races press into his page; if he mentions one trade or occupation, all other trades and occupations follow. A long procession of living forms passes before him; each several form, keenly inspected for a moment, is then dismissed. Men and women are seen en masse, and the mass is viewed not from a distance, but close at hand, where it is felt to be a concourse of individuals. Whitman will not have the people appear in his poems by representatives or delegates; the people itself, in its undiminished totality, marches through his poems, making its greatness and variety felt. Writing down the headings of a Trades' Directory is not poetry; but this is what Whitman never does. His catalogues are for the poet always, if not always for the reader, visions - they are delighted - not perhaps delightful-enumerations; when his desire for the perception of greatness and variety is satisfied, not when a really complete catalogue is made out, Whitman's enumeration ends; we may murmur, but Whitman has been happy; what has failed to interest our imaginations has deeply interested his; and even for us the impression of multitude, of variety, of equality is produced, as perhaps it could be in no other way. Whether Whitman's habit of cataloguing be justified by what has been said, or is in any way justifiable, such at least is its true interpretation and significance. (Dowden, 194)

In certain respects, then, the enumeration in "Authors" reflects the emblematic Whitman catalog. Recall that Whitman concurred with those 
critics who said that his catalogs were nothing more than a compilation of names: "They call the catalogues names, but suppose they do? It is names, but what could be more poetic than names?"12

Literary society in the nation's capital was a subject of special interest to Whitman, who always warmed to the topic of American cultural nationalism. Indeed, the article attempts to satisfy the urgent need identified by Whitman in Democratic Vistas:

Our fundamental want to-day in the United States . . . is of a class . . o of native authors, literatuses, far different, far higher in grade than any yet known, sacerdotal, modern, fit to cope with our occasions, lands, permeating the whole mass of American mentality, taste, belief, breathing into it a new breath of life. (PW 2:364)

Whitman was ruminating on this theme at the time the "Authors" article was written, as indicated by his reference to Democratic Vistas in separate letters written to Rudolf Schmidt and Edward Dowden shortly after "Authors" was published. In the Schmidt letter, for example, Whitman wrote, “The central purpose of 'Democratic Vistas' is to project $\&$ outline a fresh $\&$ brawny race of original American Imaginative authors, with moral purpose, Hegelianism, underlying their works, poemsand with Science \& Democracy - also thoroughly religious-(not ecclesiastical or sectarian merely)" (Corr. 2:151).

The enumerations in "Authors" reflect Whitman's broad view of literature, which, he claimed in Democratic Vistas, "tills its crops in many fields" ( $P W 2: 367)$. Represented in the article are writers in such diverse fields as law, medicine, astronomy, physics, political science, music, history, medicine, natural science, philology, philosophy, biography, journalism, literary criticism, engineering, fraternity, poetry, fiction, ethnography, and religion. Such an expansive range was typical of Whitman's interests. In scanning the poet's collection of newspaper clippings, Greenspan notes that "they cover a breadth and variety of fields more befitting the curriculum of a modern university than that of a college of his own day - a measure not only of the range of his interests but also of the variety of influences pouring into his poetry" (Greenspan, 74). And Whitman's intimate friend during his Washington years, Ellen O'Connor, recalled that their shared circle of friends at the time formed a veritable Philomathesian Society, in which "no subject, whether under the heaven above or in the earth beneath, was ignored. Philosophy, history, religion, literature,-authors, ancient and modern,-language, music, and every possible question as to the conduct of the Civil War,everything was discussed and every side was heard." 13

There is a special emphasis in the "Authors" enumerations on the contributions of journalists and men of science. This corresponds to the belief expressed by Whitman in Democratic Vistas that, "In the department of science, and the specialty of journalism, there appear, in these 
States, promises, perhaps fulfilments, of highest earnestness, reality, and life" (PW 2:367). As essential as other endeavors were to the making of a national literature, however, Whitman believed that "never was anything more wanted than ... the poet of the modern is wanted, or the great literatus of the modern" (PW 2:365). Fittingly, the "Authors" enumeration leads off with none other than "Walt Whitman."

Interspersed through the enumeration are reference works concerning the Civil War, including Newcomb's economic treatise, McPherson's political history, Boynton's naval accounts, and Billing's description of the barracks and hospitals. This emphasis is also typical of Whitman, who believed the "Four Years' War" contained "the richest masses of material ever afforded a nation, more variegated, and on a larger scale" (PW 2:413), which could serve as a foundation for the development of a national imaginative literature. The published enumerations exhibit a Hegelian interplay of opposites, which is characteristic of "the poet of slaves and of the masters of slaves" (NUPM 1:67). It finds room for Southern abolitionist Francis Colburn Adams and antebellum apologist Mary Henderson Eastman; Whitman champion W. D. O'Connor, and Interior Secretary James Harlan's defender Charles Lanman; Union Colonel Richard J. Hinton and Confederate General Albert Pike.

The Yale manuscript anticipates an enumeration of authors. In particular, on the third sheet, between his profiles of O'Connor and Burroughs, Whitman makes a note to himself to "(Mention various personages)." Again on the fourth sheet, after mention of O'Connor and before his own profile, Whitman writes,

\section{Also several titt literary men, and not a few ladies, from the West, South, and of our own District. (Collect names of others)}

Finally, the fifth sheet contains an enumeration of fifteen named Washington personalities, including one, Charles Astor Bristed, who is specifically included in the "Authors" article. The wealthy Bristed established a Washington residence to lobby Congress to pass international copyright legislation, a cause Whitman supported elsewhere in the manuscript. $^{14}$

The enumeration also proposes to list

Professors \& scientific gentlemen of of the Naval Observatory

Smithsonian Institute, Coast Survey \& hydrographic

\& signal offices

This notation may be the genesis for the listing in "Authors" of astronomer Simon Newcomb of the naval observatory, Secretary Joseph Henry 
and zoologists Spencer Fullerton Baird and Theodore Gill of the Smithsonian Institution, and geodesist Julius Erasmus Hilgard and astronomer Benjamin Peirce of the U.S. Coast Survey.

Other institutions enumerated further down on the fifth manuscript sheet include:

\section{Headquarters of the Army}

Diplomatic representatives \& their families \& staffs

Several enumerated authors in the Evening Star article were military men, including John Shaw Billings, George Alexander Otis, and Joseph Janvier Woodward of the U.S. Army Surgeon General's Office, and Andrew Atkinson Humphreys of the U.S. Army Corps of Engineers. Diplomatic staff included Charles Lanman, the American secretary of the Japanese legation. ${ }^{15}$

Still other enumerated authors are associated with institutions listed on the third manuscript sheet:

The advantages here are such as The Congressional Library, (one

of the first class ones of the

world)-

To some extent we are already A literary centre- esp (this is especially

true of Journalists)

Educational-Georgetown College

Columbian College Howard University

Health

Ainsworth Spofford, mentioned by name in both "Winter Residence" and "Authors," was the Librarian of Congress whose view of literature Whitman had quoted approvingly in Democratic Vistas:

"The true question to ask," says the librarian of Congress in a paper read before the Social Science Convention at New York, October, 1869, "The true question to ask respecting a book, is, has it help'd any human soul?" (PW 2:419-20)

The colleges mentioned in the manuscript have their representatives in Dr. Flodoardo Howard, a founder of Georgetown University Medical School, and President James C. Welling and Professor Samuel Tyler of Columbian College (now the George Washington University). The notation of "Health" may have inspired mention of prominent local physicians Dr. Joseph M. Toner, founder of Providence Hospital, and Dr. 
Tullio S. Verdi, a gynecologist who served on the District of Columbia's Board of Health.

A large number of the enumerated authors were journalists. As mentioned earlier, Whitman's manuscript particularly emphasizes their role in Washington's literary society. In addition to Campbell, Townsend, and Poore, the list includes Greenwood, a contributor to the New York Tribune and New York Times; Donn Piatt, editor of the independent Washington weekly, the Capital; and Lawrence Augustus Gobright, correspondent for the Associated Press. Also included in the first enumeration are Richard J. Hinton, correspondent for the Cincinnati Commercial and the New York Evening Mail; and John James Piatt, contributor to the Columbus Morning Gazette. Journalists who are found in the second installment's catalogue include Nathan Sargent, former correspondent of the U.S. Gazette under the by-line "Oliver Oldschool"; J.B. Russell; Mary Clemmer Ames, letter writer for the New York Independent and Brooklyn Daily Union; Nathaniel Shatswell Dodge, former correspondent for the National Intelligencer and the National Republican, and occasional contributor to various magazines on agricultural topics; W. R. Hooper, contributor to Appletons' Fournal and Scribner's Monthly magazines; and Eliab Kingman, formerly of the Baltimore Sun. Reminiscing with Horace Traubel one day, Whitman noted that "the newspaper boys always had a more or less friendly feeling towards meperhaps it was an expression of clannishness, for they are clannish for their own men - and in Washington I got along well with all."16

Other enumerated authors contributed fiction, poetry, or items of general interest to the newspapers and magazines: Albert Pike, Freemasonry and philology; Bristed, sports, politics, and international copyright; Sarah Bryan Piatt, poetry; Harriet Prescott Spofford, fiction; Francis Colburn Adams, political fiction and military history; De Benneville Randolph Keim, travelogues and military history; Lanman, politics, nature, and travel; Frances Baden, juvenile fiction; and Boyle, poetry and biography. Whitman's correspondence and notebooks, as well as his recorded Camden conversations with Horace Traubel, indicate that the poet was personally acquainted with many of the enumerated authors. In addition to his well-known friendship with O'Connor and Burroughs, Whitman knew George Alfred Townsend, Benjamin Poore, Donn Piatt, John and Sarah Piatt, Harriet Spofford, and Richard Hinton. ${ }^{17}$

All things considered - the supporting manuscripts, the characteristic catalogs, the subject matter, the familiar thematic concerns, and his personal acquaintance with many of the writers mentioned-it seems reasonable to conclude that Whitman was the author of "The Authors of Washington." 


\section{NOTES}

1 I am indebted to Marilyn Barth, Kevin J. Murray, Sherwood Smith, and Kurt Vorndran for their helpful comments on a draft of this paper.

2 See, for example, Emory Holloway, "Whitman as His Own Press-Agent," American Mercury 18 (December 1929), 482-488; F. DeWolfe Miller, "He Wrote Items for the Star: Struggling Walt Whitman Had Press Agent's Skill," Washington Evening Star (July 30, 1961), C3; and Martin G. Murray, "The Poet-Chief Greets the Sioux," Walt Whitman Quarterly Review 17 (Summer 1999/Fall 1999), 25-37.

3 The transcription of the manuscript relies heavily on that found in Notebooks and Unpublished Prose Manuscripts, ed. Edward Grier (New York: New York University Press, 1984), 2:912-916; reproduced in Major Authors on CD-Rom: Walt Whitman, ed. Ed Folsom and Kenneth M. Price (Woodbridge, CT: Primary Source Media, 1998).

4 Although Whitman's hand is not clearly legible, it is possible that he wrote:

Art Donation

Corcoran Gallerie

5 The opening statement that government employment is "not incongenial with literary pursuits," is similar to an expression used by Whitman in a May 13, 1867, letter to Abby Price, in which he observed: "find my work mild \& agreeable, \& the place one remarkably well suited to a lazy, elderly, literary gentleman." See The Correspondence, ed. Edwin Haviland Miller (New York: New York University Press, 1961), 1:319-320; reproduced in Major Authors.

6 Edward Dowden, Westminster Review 96 (July 1871), in Contemporary Reviews of Whitman's Work, ed. Kenneth M. Price (New York: Cambridge University Press, 1996), 194.

7 Ezra Greenspan, Walt Whitman and the American Reader (Cambridge: Cambridge University Press, 1990), 75.

8 I am indebted to Martin Buinicki for sharing with me a draft of his essay, "Walt Whitman and the Question of Copyright" (forthcoming in American Literary History), which discusses Whitman's longstanding support for literary property rights.

9 Prose Works 1892, ed. Floyd Stovall (New York: New York University Press, 1964), 2:574-576; reproduced in Major Authors.

10 Walt Whitman, "Letters from a Travelling Bachelor," New York Sunday Dispatch, October 14, 1849, to January 6, 1850; in Joseph Jay Rubin, The Historic Whitman (University Park: Pennsylvania State University Press, 1973), 353-354.

11 James Perrin Warren, “'Catching the Sign': Catalogue Rhetoric in 'The Sleepers'," Walt Whitman Quarterly Review 5 (Fall 1987), 16-34.

12 Horace Traubel, With Walt Whitman in Camden, ed. Sculley Bradley (Philadelphia: University of Pennsylvania Press, 1953), 4:324.

13 Ellen M. Calder, "Personal Recollections of Walt Whitman," Atlantic Monthly 99 (June 1907), 825-834; reproduced in The Atlantic Online, at www.theatlantic.com.

14 Bristed's establishment of a Washington, D.C., residency to lobby on behalf of international copyright is mentioned in an article in the New York Evening Mail, December 7,1870 .

15 See entry on Lanman in the Dictionary of American Biography. 
16 Horace Traubel, With Walt Whitman in Camden (Carbondale: University of Southern Illinois Press, 1992), 7:37. Hereafter $W W C$.

17 For Whitman's relationship with Townsend, see Corr., 1:329, 5:291; NUPM, 2:831; $W W C, 3: 330,333$, and 8:516-517; and George Alfred Townsend, "Letter," Cleveland Leader (September 23, 1868). For Whitman's relationship with Poore, see Corr., 3:22, WWC, 1:391-392, and Willard E. Martin, Jr., "Whitmaniana from the Boston fournal," Walt Whitman Review 23 (June 1977), 90-92. For his relationship with Harriet Spofford, see $W W C, 1: 103-104$, and 3:564. For his relationship with Donn Piatt, see $W W C, 3: 23$, and 7:37. For his relationship with John and Sarah Piatt, see Corr., 1:281; NUPM, 2:831; John James Piatt, "From Washington: Literature in Political Harness," Columbus Morning fournal (February 12, 1866), 1; and Piatt, "To Walt Whitman, the Man," Cosmopolitan (November 14, 1892), 118. For his relationship with Hinton, see $W W C, 2: 123,396$; Richard J. Hinton, "Why Walt Whitman Left the Interior Dept.," Milwaukee Sentinel (February 9, 1866), 2:4-5; Hinton, "The Poet Walt Whitman-His Fame and Fortunes in England and America-His Present Position," Rochester Evening Express (March 7, 1868); Hinton, "Washington Letter: Walt Whitman Personally, Poetically and Prospective," Cincinnati Commercial (August 26, 1871), 1-2; Hinton, "Walt Whitman in Europe," Kansas Magazine (December 1872), 499-502; Hinton, "New York Letter . . . Walt Whitman," Cincinnati Commercial (February 25, 1873), 2; Hinton, "Walt Whitman at Home-An Interesting Visit to the Famous Poet's Humble Sick-Room," New York World (April 14, 1889), 28:1-3, Hinton, "Walt Whitman and His Friend 'Jack'," Nerw Voice (February 4, 1899), 2; and Horace Traubel, Camden's Compliment to Walt Whitman (Philadelphia: David McKay, 1889), 68. 